\title{
Biochemical Profiling of Blood Serum of Male Albino Rats Treated with Various Seed Oils
}

\author{
Hanan Mohammed Munhal Musa ${ }^{1}$ and Hatil Hashim EL-Kamali*2 \\ ${ }^{I}$ Department of Biotechnology, Faculty of Science and Technology, Omdurman Islamic University, Omdurman, Sudan \\ ${ }^{2}$ Department of Botany, Faculty of Science and Technology, Omdurman Islamic University, Omdurman, Sudan \\ Corresponding Email address: hatilhashim@gmail.com
}

To cite this article:

Hashim EL-Kamali, H., \& Mohammed Munhal Musa, H. (2022). Biochemical profiling of blood serum of male albino rats treated with various seed oils. Omdurman Islamic University Journal, 18(1), 41- 47. https://doi.org/10.52981/oiuj.v18i1.2034

\begin{abstract}
This study aimed is to investigate the biochemical effects of seed oils extracted from Adansonia digitata, Balanites aegypticia, Lawsonia inermis, Ziziphus spina- christi and Trigonella foenumgraecum on male albino rats. The rats were divided into six groups; each group consisted of 5 rats, namely, Group 1, 2, 3, 4, 5 and Group 6. Group 1 was considered as control. Groups 2 - 6 were considered as experimental groups treated with oils for each group, respectively. One ml oil was administered oral dose for 14 days. The levels of urea (in A.digitata and B.aegyptiaca oils), uric acid (in B.aegyptiaca oil), Na+ (in A.digitata oil), glucose, Alkaline phosphatase (ALP), Aspartate aminotransferase (AST) and Alanine aminotransferase (ALT) (in B.aegyptiaca, L.inermis and Z.spina-christi oils) were significantly different while compared to the control groups $(\mathrm{P}<0.05)$. Therefore, the use of Adansoina digitata oil as a supplementary feed ingredient should be thoroughly considered.
\end{abstract}

Keywords: Biochemistry, seeds fixed oils, Adansoniadigitata ,Balanitesaegypticia , Lawsoniainermis , Ziziphusspina-Christi and Trigonellafoenum-graecum male albino rats

\section{Introduction}

Herbal medicines have received greater attention as an alternative to clinical, leading to increased demand, but there are little data about the effects of candidate seed oils on serum blood parameters. The available literature relatedon the oils understudy in this field is insufficient, so is more research is urgently needed. 
Adansonia digitata L. is a native deciduous tree of Africa savannas and belongs to the family Bombacaceae. The oil extracted from the seeds is used against diarrhea [1]. The Balanites aegyptiaca belongs to the family Balanitaceae is used to treat so many illnesses, including diarrhea, hemorrhoid, stomach aches, jaundice, yellow fever, syphilis, and epilepsy, as a laxative[2]. For instance, the fruit is used to treat liver disease and as a purgative and sucked by schools children as a confectionary in some countries [3].

Previous studies suggest that Zizyphusspina-christi (Rhamnaceae) can be very useful in controlling of hepatic and nephrotic abnormalities [4]. Trigonellafoehnum-graecum is a member of the family Fabaceae. The seeds possess anti-diabetic potentials [5]. T. foenum-graecum seeds can lower blood glucose and cholesterol in type 1 and type 2 diabetics and experimental diabetic animals [6].

Lawsonia inermis"Henna" is a member of the family Lythraceae. The L. inermis extract decreased the concentration of glucose, cholesterol and triglycerides to normal [7]. Methanolic (95\%) extract of leaves showed significant anti-hepato-proptective effect [8]. This study seeks to evaluate the effects of candidate plants seeds crude oil on biochemical profiles on blood of albino rats.

\section{Materials and Methods}

\section{Plants material:}

Five samples of seed oils were extracted manually by cold-pressed method from plants of $A$ danosonia digitata L "Tebaldi", Balanitea aegyptiaca "Hejleej”, Lawsonia inermis "Henna " , Ziziphus spina-christi "Sedder " and Trigonella foenum-graecium "Helba " were purchased from Omdurman Market, Khartoum State (Central Sudan) in June 2014. The Samples were identified by one author (Prof H.H Elkamali).

\section{Animals used:}

Thirty male albino rats weighing 85 grams were obtained from University of Khartoum, Faculty of Pharmacy and they were allowed to acclimatize for 14 days prior to the experiment. The animals were housed in plastic cages in a well-ventilated room and then were divided into six groups, each group contain five animals and were used as experimental animals for biochemical study.

\section{Experimental design:}

Thirty male albino rats were divided into six groups, namely, Group 1, 2, 3, 4, 5 and Group 6. Groups 1 served as normal control. Groups 2, 3, 4, 5 and 6 rats were orally administered one ml oil for 14 days of Adanosonia digitata L, Balanitesa egyptiaca, Lawsonia inermis, Ziziphusspina- 
christi, and Trigonellafoenum-graecum for each group, respectively. Then the blood samples were collected for some biochemical examination.

\section{Biochemical assays:}

Serum biochemistry was carried out on each sample. The biochemical parameters selected are creatinine, blood urea, uric acid, $\mathrm{K}+\mathrm{Na}+$, cholesterol, glucose, total bilirubin total protein, albumin and liver enzymes including Alkaline phosphatase (ALP), Aspartate Transaminase (AST) and Alanine Transaminase (ALT).

\section{Statistical Analysis:}

All values obtained were calculated as mean \pm standard deviation and the statistical significance of differences between mean values was determined using the SPSS for Windows version 11.0 Statistical program (Chicago, IL, USA). Study groups were compared with the control group by applying the t-test. For all statistical evaluations, $\mathrm{p}$ values $<0.05$ were recognized as statistically significant [ 9 ].

\section{Results and Discussion}

The biochemical effect of seed oils of Adansonia digitata, Balanites aegypticia, Lawsonia inermis , Ziziphus spina-christi and Trigonella foenum-graecum were evaluated in male albino rats during 14 days administration of one $\mathrm{ml} / \mathrm{Kg}$ b.w, orally. Parameters evaluated include creatinine, blood urea, uric acid, $\mathrm{K}+, \mathrm{Na}+$, cholesterol, glucose, total bilirubin total protein, albumin and liver enzymes including Alkaline phosphatase (ALP), Aspartate Transaminase (AST) and Alanine Transaminase (ALT). The results of biochemical parameters is are reported in Table 1.

The levels of uric acid and creatinine were remained unaltered by the studied oils. The relative increase in urea by A.digitata oil and the relative decrease in B.aegyptiaca oil were observed in treated groups 2 and 3.

There is no glomerular dysfunction because there is no significant changes $(\mathrm{P}<0.05)$ in the levels of creatinine [10]. The non-significant change in sodium and potassium ions levels may support that the biochemical indices of toxicity investigated in this study were not affected by the action of seeds oils.

All rats groups, which treated with the studied seed oils, showed no significant difference in the cholesterol levels compared to the normal rats. This result agreed with previous finding stated that Trigonella foenum -graecum in traditional medicine used to prevent hypercholesterolemia [11] and with Khosla et al. 1995 [6] who found that Trigonella foenum -graecum seeds lowered plasma cholesterol. 
Seed oils of Balanites egyptiaca, Lawsonia inermis, Ziziphus spina - christi and Trigonella foenum -graecum caused a significant decrease in the level of glucose ( $\mathrm{P}<0.05)$. This is an interesting finding which may suggest that these plants seed oils could be utilized to control diabetic's problem. This agreed with Khosla et al., 1995 [6] who found that Trigonella foenum graecum seeds can lower blood glucose in type 1 and type 2 and experimental diabetic animals. Also Lawsonia inermis extract decreased the concentration of glucose to normal [7], while seed oil of Adansonia digitata show a significant increasing $(\mathrm{P}<0.05)$ compared to the control.

Seed oil of Lawsonia inremis exhibit a significant increase $(\mathrm{P}<0.05)$ in the level of total protein, whereas seed oils of Adansonia digitata, Balanitesa egyptiaca, Ziziphusspina - Christi and Trigonellafoenum-graecum show insignificant difference $(\mathrm{P}>0.05)$ compared to the control. The elevated level of serum total protein in Lawsonia inermis could possibly imply increase in functional activity of the liver caused by the component of the seed oil [12]. Evaluation of serum proteins such as albumin is a good criteria for assessing the secretary ability/ functional capacity of the liver [13]. Seed oil of Lawsonia inermis caused a significant increase in the level of albumin relative to control, while seed oil of the rest plants show an insignificant difference $(P>0.05)$.

The rats' groups treated with the seed oils of Adanosonia digitata (Group 2) and Trigonella foenum-graecum ( Group 6 ) showed no significant differences in ALT enzyme level compared to the normal rats group 1 ( control ), but rats groups treated with the Balanitesa egyptiaca (Group 3 ) , Lawsoniainermis ( Group 4 ) and Ziziphusspina - Christi ( Group 5) showed a significant decreasing in ALT level compared to normal rats (control).

The rats of Group 2 and Group 6 which treated with the seed oils of different studied plants showed a significant increase of AST enzyme levels compared to normal rats (control). High level of AST is generally accompanied by significant elevation in ALT levels, which is not observed in the present work. This could partly explain the fact that the liver is not seriously affected by the crude oils of these plants

The reduced level of serum ALP in the rat groups treated with oils of Balanites aegyptiaca, Lawsonia inermis, Ziziphus spina- christi and Trigonella foenum-graecum after 14 days may due to inhibition of the enzyme activity at the cellular and molecular levels. No significant ( $p>0.05)$ changes in serum total bilirubin or total protein, further the suggesting that of liver is not seriously affected by the oils. 
Table 1. Biochemical parameters of some seed fixed oils in male albino rats

\begin{tabular}{|c|c|c|c|c|c|c|}
\hline \multirow[t]{2}{*}{ Parameters } & \multirow[b]{2}{*}{$\begin{array}{l}\text { Control } \\
\text { Group1 }\end{array}$} & \multicolumn{5}{|c|}{ Crude oil } \\
\hline & & $\begin{array}{l}\text { Adansoniadigitata } \\
\text { Group } 2\end{array}$ & $\begin{array}{l}\text { Balanitseaegyptiaca } \\
\text { Group } 3\end{array}$ & $\begin{array}{l}\text { LawsoniainermisL } \\
\text { Group } 4\end{array}$ & $\begin{array}{l}\text { Ziziphusspinn, } \\
\text { chist } \\
\text { Group } 5\end{array}$ & $\begin{array}{l}\text { TrangonellagraecumL } \\
\text { Group } 6\end{array}$ \\
\hline Creatinine mg/dl & $0.58 \pm 0.13$ & $0.50 \pm 0.173$ & $0.56 \pm 0.15$ & $0.56 \pm 0.11$ & $0.50 \pm 0.15$ & $0.62 \pm 0.12$ \\
\hline Urea mg/dl & $40.0 \pm 4.41$ & $48.00 \pm 9.64^{*} \uparrow$ & $34.40 \pm 5.85^{*} \downarrow$ & $34.00 \pm 4.06$ & $35.4 \pm 5.81$ & $38.75 \pm 2.98$ \\
\hline Uric Acid mg /dl & $4.00 \pm 0.84$ & $4.40 \pm 0.62$ & $3.92 \pm 0.58^{*} \quad \downarrow$ & $4.06 \pm 0.49$ & $3.98 \pm 0.34$ & $4.37 \pm 0.73$ \\
\hline $\mathrm{K}^{+} \mathbf{m m o l} / \mathbf{l}$ & $3.28 \pm 0.21$ & $3.06 \pm 0.15$ & $3.14 \pm 0.19$ & $3.26 \pm 0.24$ & $3.26 \pm 0.18$ & $3.22 \pm 0.20$ \\
\hline $\mathrm{Na}^{+} \mathrm{mmol} / \mathrm{l}$ & $142.0 \pm 2.12$ & $138.00 \pm 1.73^{*} \downarrow$ & $142.00 \pm 1.58$ & $139.80 \pm 3.34$ & $142.00 \pm 1.92$ & $142.00 \pm 2.94$ \\
\hline Glucose $\mathbf{g} / \mathbf{d l}$ & $93.20 \pm 3.42$ & $99.66 \pm 1.52^{*}$ & $77.60 \pm 6.22^{*}$ & $68.60 \pm 2.70 * \downarrow$ & $70.80 \pm 3.56$ * & $59.25 \pm 1.70^{*} \downarrow$ \\
\hline Cholesterol g/dl & $38.80 \pm 1.92$ & $35.80 \pm 3.21$ & $36.60 \pm 3.36$ & $41.80 \pm 5.76$ & $36.00 \pm 4.30$ & $34.75 \pm 4.34$ \\
\hline Bilirubin mg /dl & $0.66 \pm 0.151$ & $0.66 \pm 0.152$ & $0.70 \pm 0.151$ & $0.72 \pm 0.19$ & $0.62 \pm 0.18$ & $0.80 \pm 0.08$ \\
\hline Protein mg /dl & $5.82 \pm 0.28$ & $6.30 \pm 0.40$ & $5.74 \pm 0.49$ & $7.00 \pm 0.29^{*}$ & $6.08 \pm 0.35$ & $5.52 \pm 0.28$ \\
\hline Albumin mg /dl & $3.08 \pm 0.22$ & $2.83 \pm 0.25$ & $3.34 \pm 1.51$ & $3.68 \pm 0.17^{*} \quad \uparrow$ & $3.08 \pm 0.22$ & $2.70 \pm 0.31$ \\
\hline ALP U/L & $298.6 \pm 48.7$ & $335.33 \pm 19.55^{*} \uparrow$ & $273.0 \pm 50.94^{*}$ & $240.6 \pm 54.97^{*} \downarrow$ & $248.0 \pm 60.83^{*} \downarrow$ & $252.75 \pm 55.45^{*}$ \\
\hline AST U/L & $65.20 \pm 13.84$ & $72.33 \pm 10.01^{*} \uparrow$ & $76.20 \pm 10.98^{*}$ & $82.40 \pm 16.13^{*} \uparrow$ & $75.00 \pm 12.86^{*} \uparrow$ & $78.00 \pm 14.67^{*}$ \\
\hline ALT U/L & $48.40 \pm 5.31$ & $51.00 \pm 9.53$ & $39.40 \pm 6.76^{*}$ & $31.40 \pm 6.18^{*} \downarrow$ & $38.40 \pm 3.80^{*}$ & $49.75 \pm 12.73$ \\
\hline
\end{tabular}

Values are expressed as Mean $\pm \mathrm{SD}^{*}$ : Significant at $(\mathrm{P} \leq 0.05)$.

$\mathrm{n}=5$, arrows $=$ indicates increment or decrement 
Hanan Mohammed Munhal Musa and Hatil Hashim EL-Kamali, Biochemical profiling of blood serum of male albino rats treated with various seed oils

\section{Conclusion:}

All rats' groups treated with the seed oils of different studied plants showed a significant increase in AST enzyme levels, showing a significant decrease of ALT levels in Balanites aegypticia, Lawsonia inermis and Ziziphus spin - christi compared to normal rats. ALP level significantly increase in rats which treated with Adansonia digitata seed oil, while showing a significant decrease of ALP levels in Balanites aegypticia, Lawsonia inermis, Ziziphus spina-christi and Trigonella foenum-graecum seed oils compared to normal rats .

The study concluded that plants' oils had no effect on renal function. The oils of Balanites aegypticia, Lawsonia inermis, Ziziphus spina -christi and Trigonella foenum-graecum showed hypoglycemic effect. Adansonia digitata show increase blood glucose level. Lawsonia inermis showed hyperproteinemia effect.All these oils showed that the liver is not seriously affected.

\section{References:}

[1] De Caluwé, E., Halamová, K., Van Damme, P.,( 2009) . Baobab (Adansoniadigitata L.): a review of traditional uses, phytochemistry and pharmacology. In: Rodolfo, H., Simon, J.E., Ho, C.-T. (Eds.), African natural plant products: new discoveries and challenges in chemistry and quality. Oxford University Press, USA, pp. 51-84

[2] Ojo OO, Nadro MS, Tella IO (2006 ); . Protection of rats by extracts of some common Nigerian trees against acetaminophen -induced hepatotoxicity.Afr.J. Biotechnol 5(9):755-760.

[3] Barley S. Zygophyllaceae.In:Watt,J.M (1962) and Breyer- Brandwijk, M.G, ed.The Medicinal and poisonous plants of Southern and Eastern Africa.LivingstoneLtd.London.:1064.

[4] Adzu B, Amos S, Amizan MB, GamanielK(2003 ); . Evaluation of the antidiarrhoeal effects of Ziziphusspina-christi stembark in rats. Acta Trop 87(2):245-250.

[5] Allen O, Allen N .(1981). The Leguminosae; A source book of characteristic uses and nodulation, Macmillan Publishers Ltd, University of Wisconsin Press., Madison,pp.511-515.

[6] Khosla P, Gupta DD, Nagpal RK. (1995) .Effect of Trigonellafoenumgraecum (Fenugreek) on blood glucose in normal and diabetic rats. Indian J PhysiolPharmacol; 2: 173-174.

[7] Reddy K. R. (1988) . Folk medicine from Chittoor district Andhra Pradesh, India used in the treatment of jaundice. International Journal of Crude Drug Research .;26:137-140

[8] Mohamed M.A., Tajeldin I.M., Mohammed A., Hassan H.M. (2016) . Effects of Lawsonia inermis L. (Henna) leaves methanolic extract on CCl4-induced hepatotoxicity in rats. Journal of Intercultural Ethnopharmacology 5(1). 
[9] Bailey R.A.,(2004). Association Schemes:Designed Experiments, Algebra and Combinatories. Cambridge Stud.Adv.Math. University Press , Cambrige, pp:387.

[10] Chawla R. (1999). Practical Clinical Biochemistry (Methods and Interpretations).Second edition. Jaypee Brothers Medical Publishers, New Delhi, India.:106 -118.

[11] Clifford A. (2001) .Mediterranean vegetables: a cook's ABC of vegetables and their preparation in Spain, France, Italy, Greece, Turkey, the Middle East, and north Africa with more than 200 authentic recipes for the home cook, Illustrated ed., Harvard Common Press., pp. $181-182$.

[12] Yakular M.T. , Bilbis L. S. , Lawal M. , Akanji M.A. (2003) Effect of repeated administration of sildenafil citrate on selected enzyme activity of liver and kidney of male albino rats .Nig .j. pure and Applied Sci.,. 18=1395.1400.

[13] Bartles .H .Bohmer M., Heirli C., (1972 ) .Clinical , Chemistry .Acta37,193 